Boletín de la Sociedad Geológica Mexicana

VOLUMEN 65, NÚM. 2, 2013, P. 307-317

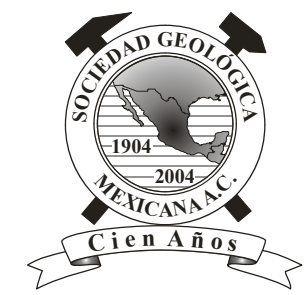

\title{
Archaeoportunus isabenensis, a new genus and species of portunoid crab (Crustacea, Decapoda) from the lower Eocene of Huesca (Spain)
}

\author{
Pedro Artal ${ }^{1, *}$, Àlex Ossó ${ }^{2}$ José Luis Domínguez ${ }^{3}$ \\ ${ }^{1}$ Museo Geológico del Seminario de Barcelona, Diputación 231, E-08007 Barcelona, Spain. \\ ${ }^{2}$ J.V. Foix, 12-H, 1er-1 a 43007 Tarragona, Catalunya. \\ ${ }^{3}$ Padre Manjón, 12, E-50010 Zaragoza, Spain. \\ *artal.pedro@gmail.com
}

\begin{abstract}
Crabs recovered from marly strata of the upper Roda Formation (lower Cuisian, Ypresian) at Isábena (Huesca, Spain) exhibit a clear set of characters, mainly in chelipeds and dorsal carapace that favour their assignment to the superfamily Portunoidea, and confirm a close relationship with the family Portunidae. However, the presence of important and easily distinguishing features, such as the strongly marked dorsal ridges or notably narrow sternum, lead us to propose a new genus and species, Archeoportunus isabenensis n. gen., n. sp., and a new family, the Archaeoportunidae n. fam. The ventral features of the new taxon, particularly the fairly narrow sternum which notably becomes even narrower posteriorly, the strongly downturned sternites 1-4 bearing strong swellings, and the general adaptation of sternum, abdomen and pereiopods, substantiate the basal condition of the new taxon within the Portunoidea and also contributes to current knowledge of evolutionary issues within that group.
\end{abstract}

Keywords: Crustacea, Decapoda, Portunoidea, Archaeoportunus, Archaeoportunidae, new family, Cuisian (Ypresian), Spain.

\section{Resumen}

Los crustáceos recuperados de los depósitos margosos superiores de la Formación Roda (Cuisiano inferior, Ypresiano) en Isábena (Huesca, España) exhiben caracteres claros que permiten su inclusión en la Superfamilia Portunoidea, en especial en lo que respecta a los quelipedos y las características dorsales, y muestran a su vez una relación cercana con la familia Portunidae. No obstante, la presencia de características importantes y fácilmente diferenciables, como son las crestas dorsales fuertemente marcadas o un plastrón esternal notablemente estrecho, nos lleva a proponer un nuevo género, Archaeoportunus isabenensis $n$. gen. $n$. sp., y una nueva familia, Archaeoportunidae n. fam. Los caracteres ventrales, en especial el plastrón esternal estrecho que se reduce posteriormente, los esternitos 1-4 fuertemente declives y con marcadas protuberancias, y la adaptación general del plastrón esternal, abdomen y pereiópodos, confirman una condición basal del nuevo taxón dentro de la Superfamilia Portunoidea, y contribuyen al conocimiento de interesantes aspectos evolutivos dentro del grupo.

Palabras Clave: Crustacea, Decapoda, Portunoidea, Archaeoportunus, Archaeoportunidae, nueva familia, Cuisiano (Ypresiano), España. 


\section{Introduction}

The well-exposed uppermost levels of the IlerdianCuisian (Ypresian, lower Eocene) sequence across the territory of the municipality of Isábena (Huesca, Spain) have yielded few crabs of relatively large size and portunoid-like appearance. As seen in the locality map (Figure 1), the crabbearing strata occur around La Puebla de Roda, the main village in the municipality. The three main sites are indicated on the map. The holotype of the new species was found in outcrops situated north of the site referred to El Villar (Figure 2; close-up view), about 300 metres southeast of La Puebla de Roda. The paratypes come from ravines near the abandoned village of Nocellas, about 8 kilometres northwest of La Puebla de Roda, and from cliffs along the eastern bank of the River Isábena, $c a .3$ kilometres south of that locality. The layers outcropping consist of grey marls and yellowgrey marly limestones with abundant nummulitids, common echinoids and very rare crab remains. Lithostratigraphically, they correspond to the Roda Formation (Cuevas-Gozalo et al., 1985) which is dated as early "Cuisian" (Serra-Kiel et al., 1994). The strata discussed in the present paper invariably occur at the top of the sequence, just above the Areniscas de Roda and the Complejo Detrítico Superior carbonated complexes (Tosquella, 1988).

There are beds with abundant crabs underlying the upper strata; Zanthopsis dufuorii (H. Milne-Edwards in d'Archiac, 1850) and Periacanthus ramosus (Artal and Castillo, 2005), have been documented. On top of the beds that are rich in the majoid P. ramosus, there are some well-developed local patch reefs, still with a highly diverse decapod crustacean fauna, numerous large-sized oysters and abundant coralgal debris. The upper levels become more terrigenous, with abundant nummulitids and faunal indicators of deeper settings, which indicate subsidence and a relatively fast change of environmental facies. This could explain the sudden change in decapod crustacean assemblages. The common Zanthopsis dufourii diminishes in overall size and abundance towards the top of the Eocene sequence, thereby gradually disappearing and finally missing from strata that

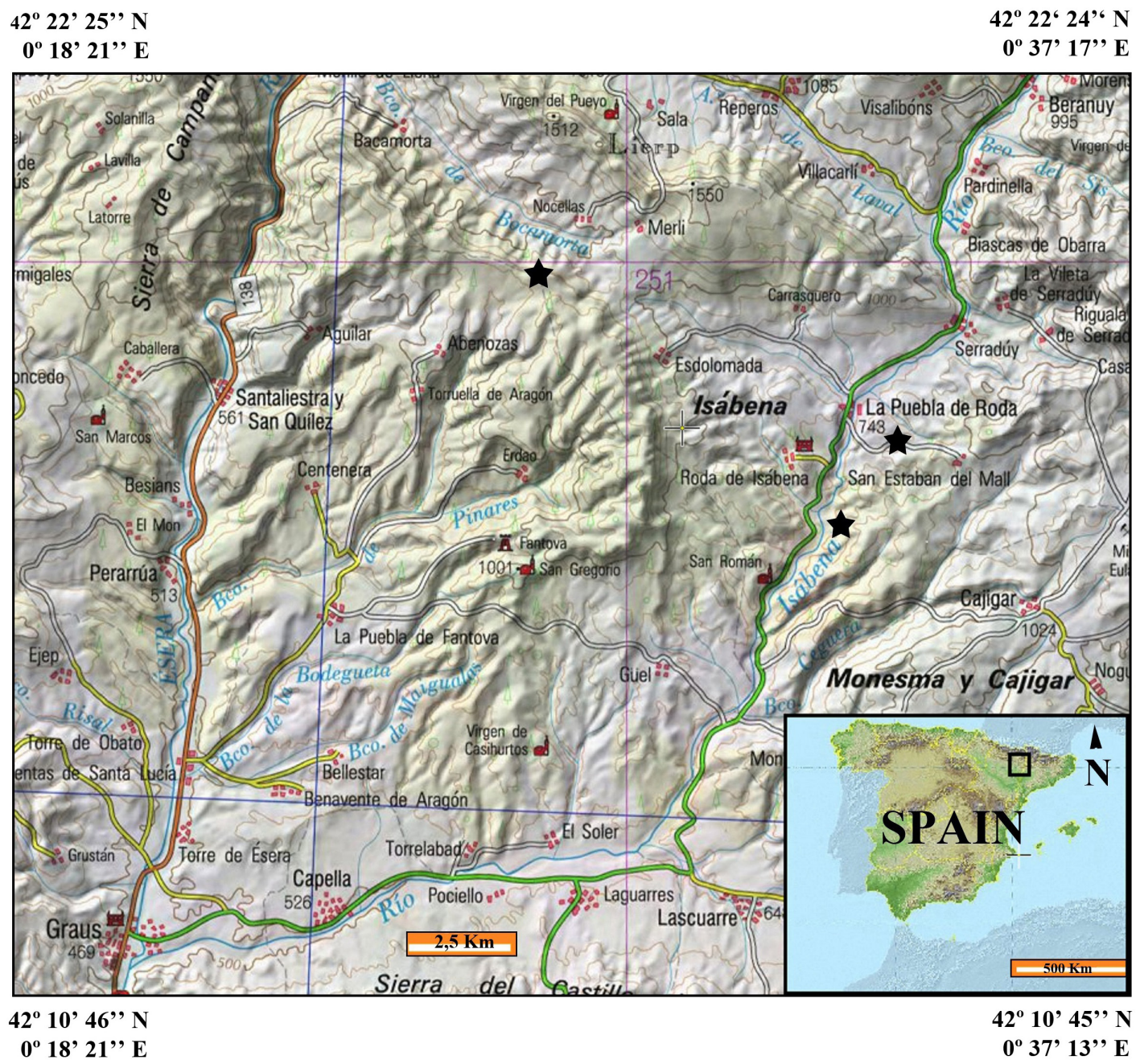

Figure 1. Map of the study area (Huesca province, Spain), showing the main sites (black stars) around La Puebla de Roda (from SIGPAC of Ministerio de Agricultura y Medio Ambiente de España). Scale bar equals $2.5 \mathrm{~km}$. 


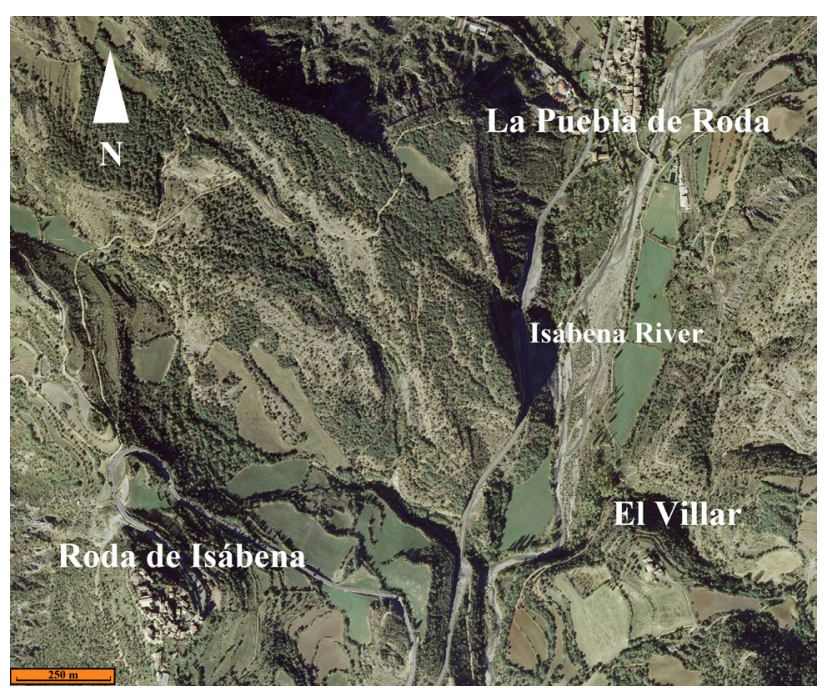

Figure 2. Close-up view of the area, showing the site referred as El Villar, where the holotype was recovered, from SIGPAC (Sistema de información geográfica de parcelas agrícolas, Ministerio de Agricultura y Medio Ambiente de España). Scale bar equals $250 \mathrm{~m}$

yield the relatively large, portunid-like crabs described in the present paper. These rare crabs are scattered, never occurring in concentrations, but are usually well preserved, disarticulated to moderate degree, co-occurring with largesized, also well-preserved echinoids, suggesting a quiet habitat, lacking high-energy conditions. Tosquella (1988) interpreted the depositional setting to have been within the shelf photic zone.

\section{Systematic Palaeontology}

Order Decapoda Latreille, 1802

Superfamily Portunoidea Rafinesque, 1815

Family Archaeoportunidae n. fam.

Type genus. Archaeoportunus n. gen.

\subsection{Diagnosis}

Large-sized carapaces, transversely subhexagonal in shape, notably wider than long, maximum width at position of epibranchial spine; orbits small, directed forwards, with two slight indentations at supraorbital margins, infraorbital margins bearing two notable teeth, fairly well visible in dorsal view; front advanced, relatively broad, with four lobes, with deep axial notch; anterolateral margins arched, bearing numerous spines including outer-orbital and epibranchial, the latter being extremely long; dorsal regions of carapace well defined by swellings and grooves; gastric, branchial and cardiac regions inflated, bearing marked ridges on top; epibranchial region defined by long, arched and salient ridge; hepatogastric and cardiobranchial grooves well marked, continuous, without interruptions; sternum relatively narrow, fairly narrowing posteriorly, strongly convex in longitudinal section; sternites 1-2 clearly separated from sternites 3-4 by complete suture; sternites 3-4 bearing three pairs of strongly marked swellings; in males, only small portion of sternite 7 visible in ventral view, sternite 8 totally covered by male abdomen; male abdomen with distinct abdominal segments $3-5$, clearly defined by complete sutures; abdominal segment 3 not much wider than 4 , reaching fifth coxa; ventral regions of carapace large, without swellings or grooves; buccal frame large; chelipeds large, stout, with thin and long fingers bearing numerous denticles; propodus ridged; pereiopods long and flattened.

\subsection{Discussion}

The subhexagonal carapace outline, being notably wider than long, the broadly arched anterolateral margins with numerous spines, the last posterior being extremely elongated, thin and arched; the features of the front, not very produced, with four lobes and a median notch, the small, forwardly directed orbits, with supraorbital fissures; the dorsal ridges, mainly the arched epibranchial keel; the large and robust chelipeds, with ridges on the propodus, and with long fingers bearing numerous denticles, are characteristic features that permit inclusion in the superfamily Portunoidea (sensu Karasawa et al., 2008) and indicate affinities with the family Portunidae Rafinesque, 1815. However, the extremely swollen and ridged dorsal regions, the markedly narrow sternum, fairly elongated and narrowing backwards, the fused sternites 3-4, with three pairs of extreme protuberances, only a small portion of sternite 7 visible in ventral view, sternite 8 being entirely covered by the male abdomen, the weakly differentiated sexual dimorphism in abdomen structure, the male abdominal segments $3-5$ being fairly distinct, defined by marked and complete sutures, are a peculiar set of characters never seen in extant or fossil members assigned to this family to date. No other families placed in the Portunoidea exhibit a similar set of features, thus the erection of a new family within the Portunoidea appears warranted. Of special interest is the fact that abdominal segment 3 is not much wider than 4 , with lateral margins converging posteriorly, not extending laterally (as typical in portunids), and abdominal segment 6 is rather short in comparison to the usually elongated segment 6 in extant portunids.

Genus Archaeoportunus n. gen.

Type species. Archaeoportunus isabenensis n. sp.

Etymology. The prefix Archaeo- indicates a primitive condition.

Archaeoportunus isabenensis n. sp.

Figures 3, 4 and 5

Diagnosis. As for genus. 


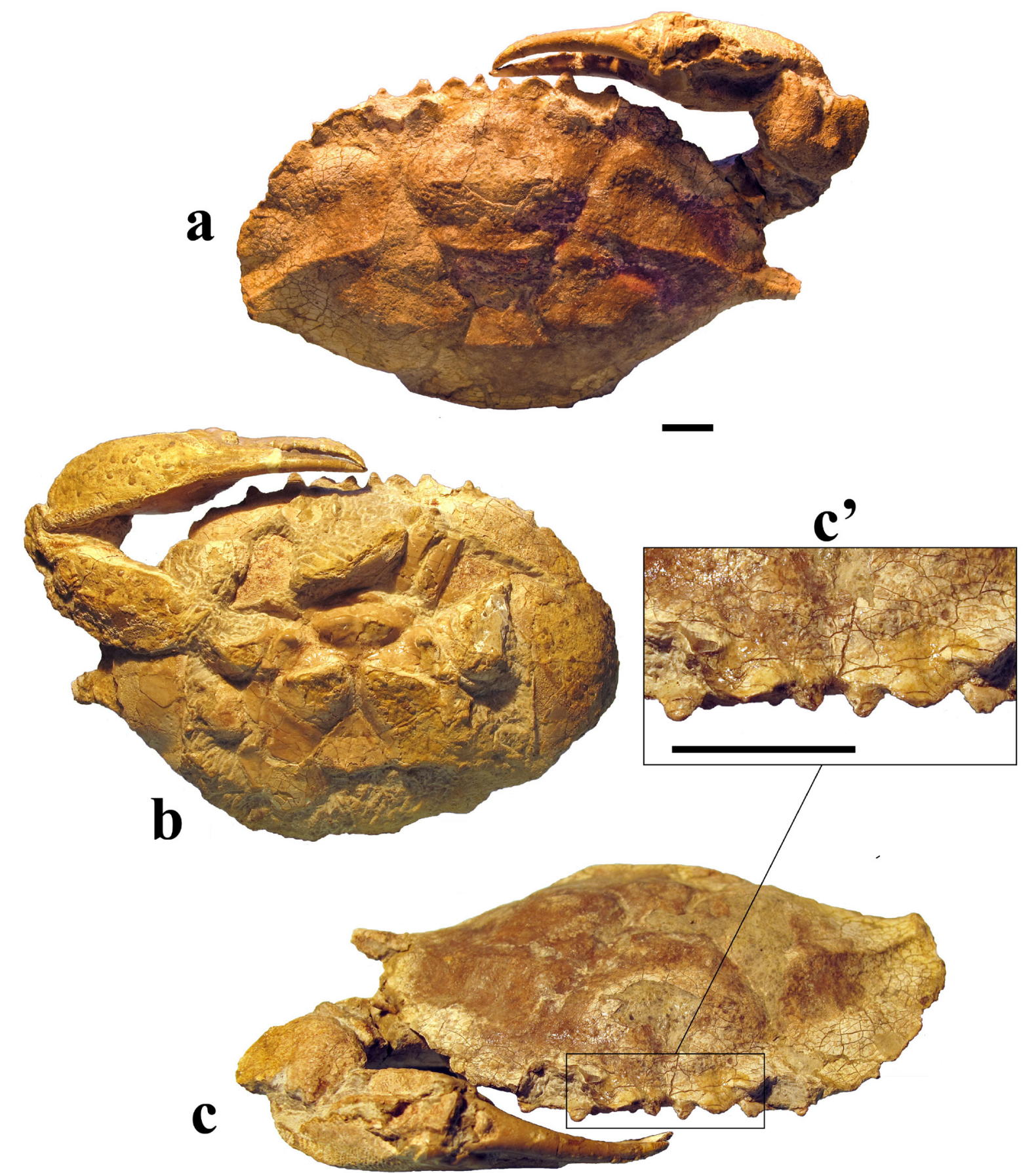

Figure 3. Archaeoportunus isabenensis n. gen., n. sp,; holotype, MGSB68576. a: dorsal view; b: ventral view; c: oblique frontal view; c': close-up view of the frontal area. All scale bars equal $10 \mathrm{~mm}$.

Etymology. From Isábena, the municipality of the province of Huesca where the crabs were collected.

Material. Holotype is MGSB68576; paratypes are MGSB68578a-b and MGSB78341. Additional material is MGSB68577. (MGSB: Museo Geológico del Seminario de Barcelona)

Measurements (in mm). Holotype MGSB68576. Carapace length $=102$, width $=68$, orbitofrontal width $=45$.

\subsection{Description}

Carapace of large size, greater than $100 \mathrm{~mm}$ in width, transversely subhexagonal, much wider than long (L/W ratio about 0.65 ), maximum width at position of epibranchial spine; dorsal surface moderately convex in both directions. Orbits small in comparison to carapace size, directed 


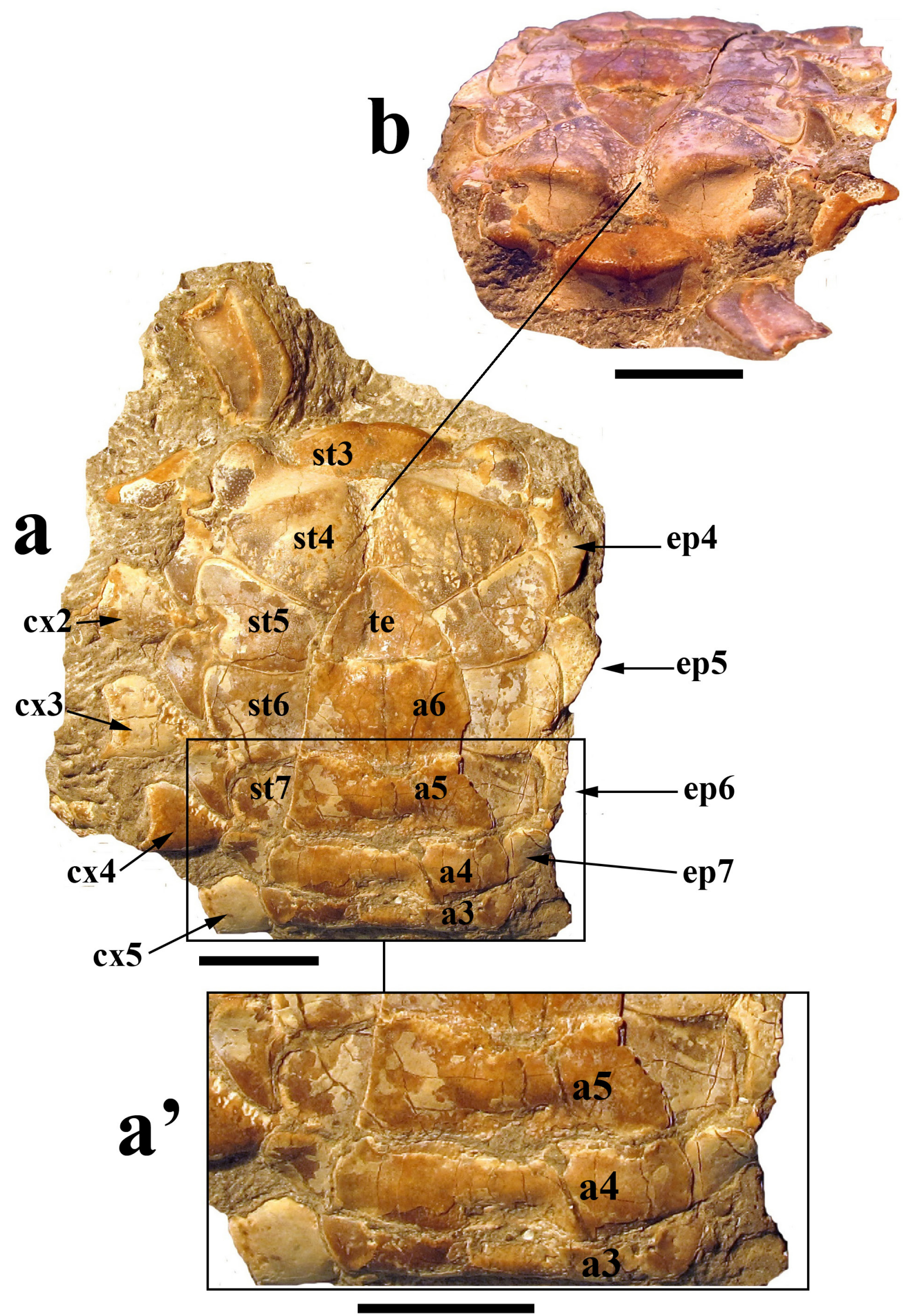

Figure 4. Archaeoportunus isabenensis n. gen., n. sp; paratype, MGSB68578a. a: complete sternum and male abdomen; a': detail of abdominal segments 3-5; b: detail of sternites 1-4. All scale bars equal $10 \mathrm{~mm}$. a (abdomen), cx (coxa), st (sternite), ep (episternite), te (telson). 

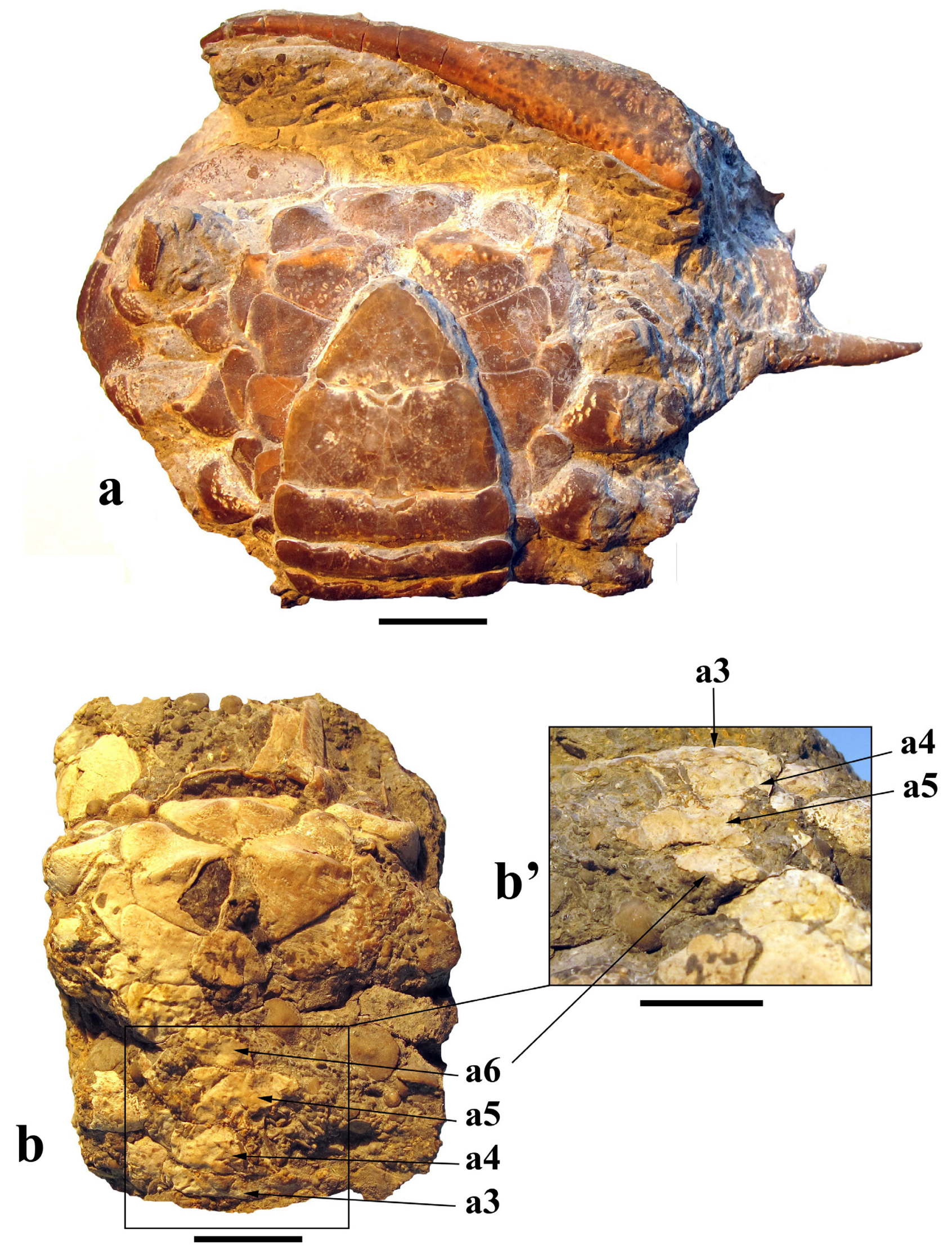

Figure 5. Archaeoportunus isabenensis n. gen., n. sp,; paratypes. a: MGSB78341, ventral view of a female; b: MGSB68578b, incomplete disarticulated specimen; b': detail of abdominal segments 3-5. All scale bars equal $10 \mathrm{~mm}$. 
forwards, bounded by discrete lobes; supraorbital margin with two slight indentations bounding a median lobe; infraorbital margin bearing two strong subtriangular teeth, fairly well visible in dorsal view. Front slightly advanced, relatively broad, with four unequal lobes, the two axial ones being slender, separated by a deep notch, the two exterior ones broadly triangular, with a sinuous base, extending towards axis. Orbitofrontal width about 0.45 of maximum carapace width.

Anterolateral margins long, arched, bearing nine spines, including outer-orbital; first seven small, discrete, last one extremely long, arched and directed outwards and downwards (see Figures 3a and 3b). Posterolateral margins slightly shorter, nearly straight, converging posteriorly. Posterior margin near straight, well defined by marked ridge, of similar size as orbitofrontal width. Dorsal regions of carapace well defined by regions and grooves. Epigastric regions distinguished by small inflations. Protogastric regions large, swollen, crossed by marked transverse ridges. Mesogastric region subtrapezoidal, raised, bearing marked transverse ridge; no clear anterior process. Urogastric region slightly inflated. Hepatic region slightly swollen, bounded transversely by shallow depressions. Epibranchial region with arched, oblique ridge directed posteriorly. Mesobranchial region bearing strong ridges. Cardiac region large, inverted subpentagonal in shape, with transverse ridge. Intestinal region small, depressed. Gastrohepatic and branchiocardiac grooves deep, well defined, continuous, without interruptions. Ventral portions of carapace large, flat, without marked swellings or grooves. Pterygostomial region large, flat.

Sternum subovate, elongated, relatively narrow, strongly convex longitudinally, clearly narrowing posteriorly. Sternites 1-2 fused, small, triangular, fairly well separated by suture from sternite 3 . Sternites 1-3 strongly downturned. Sternites 3-4 large, of robust appearance, with strong inflations and marked grooves. Sternite 3 bearing two raised swellings medially separated by a depression. Sternites 3-4 clearly differentiated by a notable lateral notch and deep oblique grooves. Sternite 4 bearing two raised, slightly oblique and strongly marked ridges separated by longitudinal groove; lateral margins of sternite 4 bearing strong, raised protuberance. Sternites 5-7 clearly bounded by sutures, episternites well developed, with broadly rounded sides. Sternite 7 only partially visible in ventral view. Sternite 8 not visible in ventral view, totally covered by male abdomen. Abdomen clearly differentiated in both sexes, with all segments fairly well separated by complete sutures; female abdomen subovate, with lateral margins broadly arched; male abdomen subtriangular. Telson triangular, reaching posterior portion of sternite 4 . Abdominal segment 6 somewhat longer than $3-5$. In males, abdominal segments 3-5 of similar size, with outer margins slightly arched, separated by clear sutures, with slight inflation in median portion. Abdominal segment 3 not much wider than 4 , with margins converging posteriorly and reaching fifth coxae.
Buccal frame large. Maxillipeds long, narrow, endopodite with relatively deep longitudinal groove; exopodite smooth, without grooves. Chelipeds large, robust; merus long, stout, dorsoventrally depressed; carpus short, globular; propodus stout, with rounded sides, ridge in lower portion; fingers very long, inner margins with numerous denticles; first denticle of moveable finger being large. Pereiopods only partially preserved, long, thin, depressed. Second to fifth coxae of similar size. Dorsal surface covered by small granules in decorticated specimens, may be smooth when cuticle appears intact.

\subsection{Remarks}

Archaeoportunus $\mathrm{n}$. gen. is here compared with both fossil and extant related families, genera and species. Eocene and Oligocene portunids from the Tethyan Realm, such as Colneptunus hungaricus Lörenthey in Lörenthey and Beurlen, 1929, Euronectes Karasawa, Schweitzer and Feldmann, 2008 (see also De Angeli and Beschin, 2008, figs. 4-6), Portunus catalunicus Via, 1941 (pl. 1), P. kochi (Bittner, 1893, p. 22, pl. 1, fig. 1; see also Beschin et al., 1996, p. 14, pl. 1, fig. 3), P. larteti (A. Milne-Edwards, 1860, p. 111; pl. 5, fig. 2), P. suessi Bittner, 1875 (p. 80, pl. 4, figs. 1a-d), P. vectensis (Carter, 1898, pl. 2, fig. 2) and P. vicentinus (A. Milne-Edwards, 1860, p. 112, pl. 6, fig. 1) all present similar carapace outlines, as well as similar orbitofrontal and anterolateral features as Archaeoportunus n. gen. However, all of them differ from the new genus in having less marked dorsal ridges, a wider sternum (widest across sternite 6 ), sternite 8 being visible in ventral view, and abdominal somites 3-5 completely fused. In addition, all of them have well-marked keels on the outer side of the propodus, whereas this is rounded in Archaeoportunus $\mathrm{n}$. gen.

The heterogeneous group of Eocene-Oligocene portunoid genera, referred to the family Macropipidae Stephenson and Campbell, 1960 by Karasawa et al. (2008), presents notable differences. Despite the fact that most members exhibit a long epibranchial spine, similar to the one in Archaeoportunus n. gen., these extinct genera are clearly distinct from the new taxon in having a different carapace outline, larger orbits, a different frontal construction and fewer anterolateral spines. In addition, the maximum carapace width is found at a more anterior position and strongly marked ridges on the dorsal carapace surface are usually absent.

Archaeoportunus n. gen. is also compared with extant portunoid families (sensu Schubart and Reuschel, 2009). Members of the family Carcinidae MacLeay, 1838, have sternite 8 covered by the male abdomen, as in Archaeoportunus n. gen., but somites 3-5 are completely fused, with abdominal segment 3 widened laterally, while in Archaeoportunus n. gen. these are distinct, with completely marked sutures. Carcinids are also distinguished by an utterly different carapace outline, not much wider than long, 
a trifid front and fewer anterolateral spines (Števčić, 2005; Karasawa et al., 2008). The family Geryonidae Colosi, 1923 , presents characters such as abdominal segments 3-5 with complete sutures, and sternite 8 not well visible in ventral view; these are features shared with the new taxon. However, this group clearly differs from Archaeoportunus n. gen. in general carapace outline, being more subquadrate, and in having fewer anterolateral spines, broader orbits and different frontal features (Karasawa et al., 2008, p. 96). The family Pirimelidae Alcock, 1899, differs from Archaeoportunus n. gen. by its produced and trilobed front, an utterly different carapace outline, being about as long as wide and abdominal somites 3-5 fused (Števčić, 2005). The family Polybiidae Ortmann, 1893, is set apart from Archaeoportunus n. gen. in displaying a carapace of near-equal width and length, fewer anterolateral spines, different frontal features, usually with a median spine, an uncovered sternite 8 and fused abdominal segments 3-5 (Karasawa et al., 2008, p. 100). The family Thiidae Dana, 1852, is easily distinguished by general carapace outline, being transversely suboval, with non-defined dorsal regions, an entire front, and all carapace margins lacking lobes or denticles and with abdominal segments 3-5 fused (Števčić, 2005, p. 33), short chelipeds adapted to the carapace, not very salient from the outline when contracted, and much shorter and more flattened pereiopods than in Archaeoportunus n. gen.

The new taxon exhibits a set of characters that confirms a close relationship to the family Portunidae (sensu Schubart and Reuschel, 2009). Archaeoportunus n. gen. is also compared to extant portunids, such as Portunus pelagicus (Linnaeus, 1758), Callinectes sapidus (Rathbun, 1896), and Arenaeus cribarius (Lamark, 1818), which were amongst the true portunids used in the revision by Schubart and Reuschel (2009, p. 536). Extant portunids have the general shape of the carapace, the anterolateral margins, the small orbits and a similar frontal construction in common with the new genus, but also notable differences as indicated in the general discussion (see below).

\section{Discussion}

The main features of Archaeoportunus permit its inclusion in the superfamily Portunoidea, sensu Karasawa et al. $(2008$, pp. 94, 95). In their diagnosis of the Portunoidea, sternite 8 was noted to be "usually visible in ventral view". However, it should be noted that the same feature was described as "not visible in ventral view" for the families Longusorbidae Karasawa, Schweitzer and Feldmann, 2008 (p. 95), Geryonidae and Carcineretidae Beurlen, 1930, (see Karasawa et al., 2008, pp. 95, 96 and 98, respectively). This is a character shared with the new genus.

Amongst families included by Karasawa et al. (2008), the new taxon presents notable similarities with the family Portunidae, e.g., the large carapace size and subhexagonal outline, being markedly wider than long; the arched anterolateral margins, bearing nine spines, the epibranchial one being very long, thin and arched; small orbits, with two fissures; a quadrilobate front and large, stout chelipeds with ridges. All these characters match the family Portunidae as diagnosed by Karasawa et al. (2008, p. 103). Of special interest is the fact that the insertion of the first coxa is at about the median portion of the lateral margin of sternite 4 , a feature seen in Archaeoportunus n. gen. and common to all portunids revised for the present study, both fossil and extant. However, it is easily distinguished from all extant and fossil portunids (sensu Karasawa et al., 2008), by certain differential features, as outlined below.

The extant Portunus pelagicus (Linnaeus, 1758) is notably different (see Lai et al., 2010) in having a nearcircular, broader sternum, sternites 1-4 with grooves, but without complete sutures; a large portion of sternites 7 and 8 fairly well visible in ventral view; episternites markedly angular, inserted between coxae; sexual dimorphism very accentuated; very narrow abdomen in males, with inverted T-shape; abdominal segment 3 strongly widened laterally, abdominal segment 6 markedly long, nearly the same size as set 3-5, which are completely fused; broadly ovate abdomen in females. With regard to dorsal features, the extant form has a front with noticeable median tooth in a lower plane, dorsal regions with less marked ridges and anterolateral margins with better-developed spines. Similar ventral differences can be confirmed if compared to Callinectes sapidus Rathbun, 1896, and Arenaeus cribrarius (Lamark, 1818) (see Rathbun, 1930, p. 134). In addition, C. sapidus differs from Archaeoportunus n. gen. in having a dorsal surface without ridges, with the exception of a well-marked epibranchial keel and strongly developed anterolateral spines. The dorsal carapace of Arenaeus cribrarius has poorly defined regions and more developed anterolateral spines. Instead, Archaeoportunus n. gen. has fairly swollen dorsal regions, with numerous and strongly marked ridges. Anterolateral margins bear very small, discrete, anterolateral spines, with the exception of the epibranchial spine which is similar in size to the one in extant portunids. The front has four different lobes: the two median ones are slender and the two exterior ones are wider, with the base extending medially. There is a clear axial notch, without median spine. Supraorbital margins have two slight indentations; deep fissures are lacking. The infraorbital margin bears two strong teeth, fairly well visible in dorsal view. The sternum is narrow, narrowing further posteriorly, with the maximum width at the position of the fifth sternite. Sternites 1-2 are fused and clearly separated from 3-4 by a complete suture. Sternites 3-4 have strongly marked ridges, two axial ones in sternite 3 , two oblique in sternite 4 and two strong inflations at the margins of sternite 4. Episternites are well developed, with broadly rounded margins, not angular. The coxae are fairly well separated. Sexual dimorphism is weak: the male and female abdomen are nearly subtriangular and of similar width. The male abdomen has distinct abdominal segments 
3-5, clearly defined by complete and well-marked sutures. Somites 3-5 have slight medial inflations, with no marked keels. Somite 3 is not much wider than somite 4 , does not extend laterally, and has lateral margins converging posteriorly. Somite 6 is short, only slightly longer than somite 5, and much shorter than set 3-5. Only a small portion of sternite 7 is visible in ventral view and sternite 8 is entirely covered by the male abdomen. In both sexes, only a discrete portion of the sternum is visible. Chelipeds have rounded lateral sides to the propodus, with a marked ridge in the lower portion of the hand.

Karasawa et al. (2008) diagnosed the superfamily Portunoidea as having poorly or moderately defined dorsal regions, an inconstant character which present distinct, fairly areolated regions, and mainly in extinct taxa. With regard to dorsal regions, Archaeoportunus n. gen. resembles other Spanish fossil portunids such as Colneptunus hungaricus and Portunus catalaunicus, but can be clearly differentiated by the more marked dorsal ridges, the peculiar shape of the front, and the number, shape and size of anterolateral spines. Portunus catalaunicus exhibits small, yet marked, protuberances on the regions, rather than ridges; the anterolateral spines are robust, salient and subtriangular, with the chelipeds strongly ridged; Colneptunus hungaricus exhibits only 5 salient anterolateral teeth, which are robust and subtriangular; it only presents faint, not strongly marked ridges on epibranchial and protogastric regions. As to ventral regions, the new taxon has in common with C. hungaricus and P. catalaunicus the position of cheliped insertion in sternite 4; sternites 1-2 are separated from sternites $3-4$ by a complete suture, with the abdominal somite 6 being short. However, Archaeoportunus n. gen. is easily distinguished by the strong protuberances in sternites $3-4$, sternite 8 being entirely covered by the male abdomen, abdominal somites 3-5 defined by clear, complete sutures, and a regularly subtriangular male abdomen, while the general shape of the male abdomen in C. hungaricus and P. catalaunicus is an inverted T, and abdominal somites 3-5 are fused. Despite the fact that differences are important, features in common indicate a possible evolutionary lineage from Archaeoportunus n. gen. to fossil portunids, which are intermediate forms, and to modern portunids, the more derived forms. The Cretaceous fossils assigned to the Portunoidea present as well some shared features, as the notable dorsal ridges in similar regions, which could indicate possible evolutionary issues.

It is worthy of note that, despite the well-marked and complete sutures on somites 3-5, we have a specimen in which ventral features are poorly preserved (Figures $5 \mathrm{~b}$ and $\left.5 b^{\prime}\right)$, with displaced portions of abdomen and coxae, somites 3-5 appearing to form an entity, while sternite 6 is separated. In fossil crabs it is difficult to be certain when an abdominal segment is free or not, moveable or not, but this example might suggest a degree of fusion in the abdominal segments.

Schubart and Reuschel (2009, pp. 533-535, 544) noted how wide ranging the interpretations of the superfamily Portunoidea have been over the years, and proposed a new classification of extant portunoids in six families, as based on two phylogenies using molecular evidence. In their discussion (pp. 544-546) these authors outlined in detail the disagreements amongst authors, but failed to indicate how to accommodate possibly related extinct genera. The nine taxa of the family Portunidae used (Schubart and Reuschel, 2009, p. 536) have constant characters that discard the attribution of the new genus to this family. However, similarities are so striking (see above) that we cannot ascribe these solely to convergent evolution.

Here we propose a new extinct family, Archaeoportunidae n. fam., to accommodate the new genus which is both similar to extant and fossil members of the family Portunidae (sensu Karasawa et al., 2008), and also exhibits important distinguishing features (see above).

Some of the families proposed by Karasawa et al., (2008), mainly the extinct ones, and some of the fossil genera assigned to extant families, seem to be very different from the Archaeoportunidae n. fam. However, a closer comparison is not devoid of interest, in order to check possible evolutionary ties. Despite the fact that most of the fossils do present some shared features, such as the swollen and ridged dorsal regions or sternite 8 not covered, they are easily distinguished by the general carapace outline, the orbits or the frontal construction, as indicated below. Although differences are remarkable, it is interesting to see how they are related, i.e., which characters they have in common and how they might have evolved.

Some features are shared with members of the family Carcineretidae (sensu Karasawa et al., 2008, p. 98), e.g., the transverse dorsal swellings on the protogastric, mesogastric, hepatic, epibranchial and cardiac regions; sternites 1-2 being separated from sternites 3-4 by a marked and complete suture; sternite 8 not visible in ventral view; and abdominal segment 3 completely filling the space between the coxae of the fifth pereiopods. However, notable differences include the subquadrate carapace outline, the extremely wide orbits, the downturned front, the insertion of the coxae of the chelipeds in the lower portion of sternite 4 , a broad portion of sternite 7 being exposed, abdominal segment 3 much wider than 4-5 extending laterally, and abdominal somites 3-5 fused (see Vega et al., 2001, p. 321, fig. 3) but with clear evidence of sutures according to Karasawa et al. (2008, p. 98).

Archaeoportunus n. gen. also has features in common with representatives of the family Longusorbiidae Karasawa, Schweitzer and Feldmann, 2008 (p. 95), such as the relatively narrow sternum, sternite 8 not being visible in ventral view, and all male abdominal segments being distinct, with notably complete sutures, entirely filling the space between the coxae of the fifth pereiopods. The sternum is narrow (Schweitzer et al., 2003, p. 46, fig.15), with a marked, complete suture separating sternites 1-2 from 3-4, similar to Archaeoportunus n. gen., but the insertion of 
the coxae of the chelipeds in sternite 4 presents an utterly different picture. As to dorsal characters, despite the fact that regions are strongly differentiated, as in Archaeoportunus n. gen., the genus Longusorbis exhibits important differences, such as the subtrapezoidal carapace outline, a much greater orbital width and utterly different frontal features.

The genus Ophthalmoplax Rathbun, 1935, which was assigned to the family Macropipidae by Karasawa et al. (2008), shares the position of the dorsal keels and the fact that male abdominal segments all have distinct sutures (see Schweitzer et al., 2003, p. 17, fig. 1; Ossó et al., 2010). It is striking to see how the Moroccan species has keels and grooves on similar regions as in Archaeoportunus n. gen. However, Ophthalmoplax differs from the new genus in having a subquadrate carapace outline, broader orbits, a downturned front, a wider sternum, a small portion of sternite 8 not covered by the male abdomen, and insertion of the chelipeds in the lower portion of sternite 4 . The family was diagnosed by Karasawa et al. (2008, pp. 100, 101 ) as having a moderately broad carapace, usually with longitudinal branchial ridges parallel to the axis, often with a carapace ornament of large granules or tubercles, and abdominal segments 3-5 fused or with different degrees of fusion. In short, the new genus cannot be accommodated in that family.

In common with geryonids, Archaeoportunus n. gen. has sternite 8 not visible and abdominal segments 3-5 distinct, with complete sutures in males. However, geryonids have a different general carapace outline, i.e., not much wider than long, with weakly defined dorsal regions, convex anterolateral margins bearing 3-5 spines, and a well-marked suture delimiting sternites 3-4 (see Karasawa et al., 2008, p. 96). Chaceon peruvianus (d'Orbigny, 1842) has a transversely ovoid sternum, uniformly elongated, with the greatest width at sternite 6 (episternite 5); sternites 1-2 are fused; suture complete 2-3; sternite 8 completely covered by the abdomen; male abdomen triangular and broad; and segment 3 broader than 4-5, but not extended laterally in the way that is seen in typical extant portunids (i.e., Portunus pelagicus). The abdomen is subtriangular in males, with the abdominal segment 3 being the widest, but not much extended laterally. Segments 3-5 are fairly distinct, with complete sutures (Schweitzer and Feldmann, 2000; Casadío et al., 2005).

On account of the extreme variability of members of the family Portunidae, detailed studies in the future need to determine a clearer distinction, mainly in fossil genera, in order to make general characteristics of the family more constant. In addition, our comparison with other extinct portunoids demonstrates that additional work is needed to obtain a more reliable subdivision in families, such as the Macropipidae, which seem to be extremely heterogeneous. Some general traits appear to be shared amongst fossil portunoids, such as the fact that abdominal somite 6 is short, sternites 1-2 clearly separated by a complete suture from sternites $3-4$, and, in some genera, the dorsal regions are strongly areolated, with very swollen regions or ridges. The elongation and width of the sternum, the shape of the abdomen, and the position of the pereiopods also indicate how a crab is modified functionally. In Archaeoportunus $\mathrm{n}$. gen. the sternum is elongated, narrowing posteriorly; abdomens, both male and female, are subtriangular, weakly differentiated; abdominal somite 3 not extending laterally; sternite 8 being covered by the male abdomen; and the coxae of the five pereiopods markedly separated. In extant portunids, the sternum is very wide and subcircular; sexual dimorphism is very pronounced: extremely narrow in males, with a typical inverted T-shape, and somite 6 very long, extremely wide in females, covering a large portion of the sternum, with episternites being angular, connected to the coxae of the five pereiopods, the coxae are approximated, which implies a clearly defined functional morphology. The shape of abdominal somite 3 , expanded laterally, being adapted to sternite 8 with a typical indentation, and the lateral margins adapted to the fifth coxae, implying an advanced degree of evolution (see Crosnier and Moosa, 2002; Lai et al., 2010). Fossil portunids clearly demonstrated an intermediate evolutionary stage, while Cretaceous portunoids assigned to the superfamily display more primitive characters.

\section{Acknowledgments}

Our warmest thanks to the staff of the MGSB, who allowed us the study of the decapod crustacean collections. We thank María Sánchez and Lluís Prieto (Barcelona, Spain), who collected and donated the holotype, Gregorio Ortega and Manuel Fernández (Anoia, Barcelona, Spain) for donation of paratypes illustrated here, and Dr. Francisco Vega (UNAM, México) and Dr. John W.M. Jagt (Maastricht, the Netherlands), who greatly improved a previous version of the manuscript with their valuable comments.

\section{References}

Alcock, A., 1899, Materials for a carcinological fauna of India. $N^{\circ} 4$. The Brachyura Cyclometopa. Part II. A revision of the Cyclometopa with an account of the families Portunidae, Cancridae and Corystidae: Journal of the Asiatic Society of Bengal, 68(2), 1-104.

Artal, P., Castillo, J., 2005, Periacanthus ramosus (Crustacea, Decapoda), nueva especie del Eoceno inferior de Huesca (Aragón, España): Batalleria, 12, 39-44.

Beschin, C., Checchi, A., Ungaro, S., 1996, Crostacei Brachiuri dell'Oligocene di Castelgomberto (Lessini orientali): Studi e Ricerche, Associazione Amici del Museo Zannato, 6, 11-20.

Beurlen, K., 1930, Vergleichende Stammesgeschichte. Grundlagen, Methoden, Probleme unter besonderer Berücksichtigung der höheren Krebse: Fortschritte der Geologie und Palaeontologie, 8(26), 317-586.

Bittner, A., 1875, Die Brachyuren des vicentinischen Tertiärgebirges: Denkschriften der Kaiserlichen Akademie der Wissenschaften, Mathematisch-naturwissenschaftliche Klasse, 34, 63-105, pls. 1-5.

Bittner, A., 1893, Decapoden des pannonischen Tertiärs: Sitzungsberichte der kaiserlichen Akademie der Wissenschaften in Wien, 102, 10-37. 
Carter, J., 1898, A contribution to the palaeontology of the decapod Crustacea of England: The Quarterly Journal of the Geological Society of London, 54, 15-44, pls. 1, 2.

Casadío, S., Feldmann, R.M., Parras, A., Schweitzer, C.E., 2005, Miocene fossil Decapoda (Crustacea: Brachyura) from Patagonia, Argentina, and their paleoecological setting: Annals of Carnegie Museum, 74, 151-188.

Colosi, G., 1923, Una specie fossile de Gerionide (Decapodi brachiuri): Bolletino della Società dei Naturisti in Napoli, series 2, 15, 248-255.

Crosnier, A., Moosa, M. S., 2002, Trois Portunidae (Crustacea, Decapoda, Brachyura) nouveaux de Polynésie française: Zoosystema, 24, 285-399.

Cuevas-Gozalo, M., Donselaar, M.E., Nio, S.D., 1985, Eocene clastic tidal deposits in the Tremp-Graus Basin (Prov. of Lérida and Huesca) in Mila, L.D, Rosell, J. (eds.), Excursion Guidebook, $6^{\text {th }}$ European Regional Meeting: Lérida, Spain, International Association of Sedimentologists, 215-266.

Dana, J.D., 1852, Conspectus Crustaceorum, etc. Conspectus of the Crustacea of the Exploring Expedition under Capt. Wilkes, U.S.N., including the Crustacean Cancroidea Corystoidea: Proceedings of the Academy of Natural Sciences in Philadelphia, 6, 73-86.

D'Archiac, A., 1850, Description des fossiles des groupes nummulitiques recueillis par M. S. P. Pratt et M. J. Delbos aus environs de Bayone et Dax: Mémoires de la Societé Géologique de France, (2)2, 397-456.

De Angeli, A., Beschin, C., 2008, Crostacei decapodi dell'Oligocene di Soghe e Valmarana (Monti Berici, Vicenza-Italia Settentrionale): Studi e Ricerche, Associazione Amici del Museo Zannato, 15, 5-35.

D’Orbigny, A., 1842, Voyage dans l'Amérique méridional, 1826-1833 (III). Géologie et Paléontologie: Paris, Pitois-Levrault, $561 \mathrm{p}$.

Karasawa, H., Schweitzer, C.E., Feldmann, R.M., 2008, Revision of Portunoidea Rafinesque, 1815 (Decapoda: Brachyura) with emphasis on the fossil genera and families: Journal of Crustacean Biology, $28,82-127$.

Lai, J.C.Y., Ng, P.K.L., Davie, P.J.F., 2010, A revision of the Portunus pelagicus (Linnaeus, 1758) species complex (Crustacea: Brachyura: Portunidae), with the recognition of four species: The Raffles Bulletin of Zoology, 58, 199-237.

Lamarck, J.B.P.A., 1818, Histoire naturelle des animaux sans vertèbres, présentant les carctères généraux et particuliers de ces animaux, leur distribution, leur classes, leurs familles, leur genres et la citation des principales espèces qui s'y rapportant; precede d'une introduction offrant la determination des caractères essentiels de l'animal, sa distinction du vegetal et les outres corps natures, enfin l'éxposition des principles fondamentaux de la zoologie; Tome 5. Deuxième edition: Paris, $612 \mathrm{p}$.

Latreille, P.A., 1802, Histoire naturelle, général et particulière, des Crustacés et des Insectes, Volume 3. Familles naturelles des genres: Paris, Dufart, $467 \mathrm{p}$.

Linnaeus, C., 1758, Systema Natura per Regna Tria Naturae, Secundum Classes, Ordines, Genera, Species, cum Characteribus, Differentiis, Synonymis, Locis. Vol. 1: Stockholm, Laurentii Salvii. iii +824 p.

Lörenthey, E., Beurlen, K., 1929, Die fossilien Decapoden der Länder der Ungarischen Krone: Geologica Hungarica (Palaeontologica), $3,1-421$.

MacLeay, W., 1838, On the brachyurous decapod Crustacea brought from the Cape by Dr. Smith, in Smith, A. (ed.), Illustrations of the Annulosa of South Africa; being a portion of the objects of Natural History Chiefly Collected During an Expedition into the Interior of South Africa, Under the Direction of Dr. Andrew Smith, in the years 1834, 1835 and 1836: London, Smith, Elder, \& Co., 53-71, pls. 2-3.

Milne-Edwards, A., 1860, Histoire des Crustacés Podophthalmaires fossils: Annales des Sciences Naturelles (Zoologie et Botanie), 4eme serie Zoologie, 14(3): 129-293, pls. 1-10.
Ortmann, A., 1893, Abtheilung: Brachyura (Brachyura genuina Boas), II. Unterabtheilung, Cancroidea, 2. Section: Cancrinea, I. Gruppe: Cyclometopa. Die Decapoden Krebse des Strassburger Museums, mit besonderer Berücksichtigung der von Herrn Dr. Döderlein bei Japan und bei den Liu-Kiu-Inseln gesammelten und zur Zeit im Strassburger Museum aufbewahrten Formen, VII. Teil: Zoologische Jahrbücher, Abtheilung für Systematik, Geographie, und Biologie der Thiere 7, 411-495, pl. 17.

Ossó, À., Artal, P., Vega, F.J., 2010, New crabs (Crustacea, Decapoda) from the Upper Cretaceous (Campanian) of the Moyenne Moulouya, northeast Morocco: Revista Mexicana de Ciencias Geológicas, 27, 213-224.

Rafinesque, C.S., 1815, Analyse de la Nature, ou Tableau de l'Univers et des Corps Organisés: Palermo, L'Imprimerie de Jean Barravecchia, $224 \mathrm{p}$.

Rathbun, M.J., 1896, The genus Callinectes: Proceedings of the United States National Museum 18, 349-375, pls. 12-28.

Rathbun, M.J.,1930, The cancroid crabs of America: Bulletin of the U.S. National Museum, 152, xvi + 1-609.

Rathbun, M.J., 1935, Fossil Crustacea of the Atlantic and Gulf Coastal Plain: New York, Geological Society of America, Special Paper 2, viii $+1-160$.

Schubart, C.D., Reuschel, S., 2009, A proposal for a new classification of Portunoidea and Cancroidea (Brachyura: Heterotremata) based on two independent molecular phylogenies, in Martin, J.W., Crandall, K.A., Felder, D.L. (eds.), Decapod Crustacean Phylogenetics (Crustacean Issues Series, 18): Boca Raton, Florida, CRC Press, 533-549.

Schweitzer, C.E., Feldmann, R.M., 2000, New fossil portunids from Washington, USA, and Argentina, and a re-evaluation of generic and family relationships within the Portunoidea Rafinesque, 1815 (Decapoda: Brachyura): Journal of Paleontology, 74, 636-653.

Schweitzer, C.E., Feldmann, R.M., Fam, J.M., Hessin, W.A., Hetrich, W., Nyborg, T.G., Ross., R.L.M., 2003, Cretaceous and Eocene Decapod Crustaceans from Southern Vancouver Island, British Columbia, Canada: Ottawa, Ontario, NRC Research Press, 66 p.

Serra-Kiel, J., Canudo, J.L., Dinares, J., Molina, E., Ortiz, N., Pascual, J.O., Samsó, J.M., Tosquella, J., 1994, Cronoestratigrafía de los sedimentos marinos del Terciario inferior de la Cuenca de Graus-Tremp (Zona Central Surpirenaica): Revista de la Sociedad Geológica de España, 7, 273-297.

Stephenson, W., Campbell, B., 1960, The Australian portunids (Crustacea: Decapoda: Portunidae) IV: Remaining genera: Australian Journal of Marine and Freshwater Research, 11, 73-122.

Števčić, Z., 2005, The reclassification of brachyuran crabs (Crustacea:Decapoda: Brachyura): Natura Croatica, 14(suppl. 1), $1-159$.

Tosquella, J., 1988, Estudi sedimentològic i bioestratigràfic de la Formació Gresos de Roda (Eocè, Conca de Tremp-Graus): Barcelona, University of Barcelona, masters thesis, $540 \mathrm{p}$.

Vega, F.J., Feldmann, R.M., Garcia-Barrera, P., Filkorn, H., Pimentel, F., Avendaño, J., 2001, Maastrichtian Crustacea (Brachyura: Decapoda) from the Ocozocuautla Formation in Chiapas, Southeast Mexico: Journal of Paleontology, 75, 319-329.

Via, L., 1941, Los cangrejos fósiles de Cataluña: Boletín del Instituto Geológico y Minero de España, 55, 55-127.

Manuscript received: September 26, 2012.

Corrected manuscript received: October 20, 2012.

Manuscript accepted: October 22, 2012. 